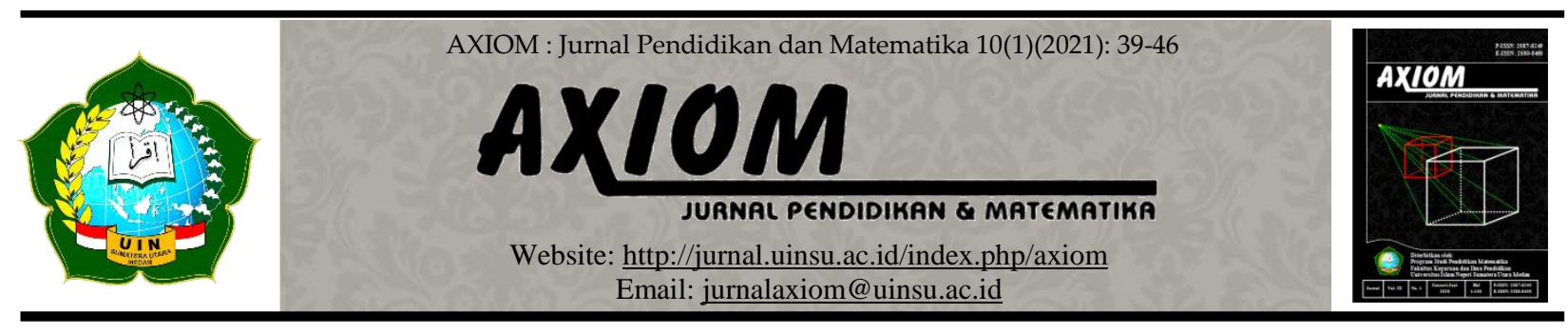

\title{
PENGARUH DISPOSISI MATEMATIS TERHADAP PEMBELAJARAN E-LEARNING PADA MAHASISWA TADRIS MATEMATIKA SEMESTER III IAIN TAKENGON
}

\author{
Oleh: \\ Bettri Yustinaningrum \\ Tadris Matematika, Fakultas Tarbiyah, Institut Agama Islam Negeri Takengon \\ E-mail: bettri_yustinaningrum@yahoo.com
}

doi : 10.30821/axiom.v10i1.8386

\begin{abstract}
Abstrak:
Pembelajaran daring agar dapat berhasil diperlukan adanya ketertarikan mahasiswa yang tinggi dalam belajar matematika. Ketertarikan yang tinggi terhadap pembelajaran matematika disebut dengan disposisi matematis. Penelitian ini bertujuan untuk mengetahui adakah pengaruh disposisi matematis terhadap prestasi belajar e-learning mahasiswa Tadris Matematika (TMA) Semester III IAIN Takengon. Populasi dalam penelitian ini adalah mahasiswa TMA IAIN Takengon. Sample dipilih dengan teknik purposive sampling yaitu mahasiswa TMA semester III. Pendekatan yang digunakan adalah pendekatan kuantitatif dengan jenis penelitian korelasi. Instrumen penelitian menggunakan tes dan non tes. Penelitian ini dianalisis menggunakan uji normalitas, uji linieritas, uji heteroskedastisitas, dan uji regresi linier sederhana. Berdasarkan pengujian regresi diketahui nilai sig $=0,003<0,05$ yang berarti bahwa disposisi matematis memiliki pengaruh signifikan terhadap prestasi belajar e-learning. Selain itu diperoleh nilai $\mathrm{R}$ square $=0,848$ menunjukan bahwa variabel disposisi matematis mempengaruhi variabel prestasi belajar e-learning sebesar $84,8 \%$ dan sebesar $16,4 \%$ variabel prestasi belajar e-learning dipengaruhi faktor diluar disposisi matematis. Besarnya koefisien korelasi (R) adalah 0,921 yang artinya terdapat hubungan yang kuat antara disposisi matematis dengan prestasi belajar $e$ learning. Model regresinya adalah $\mathrm{Y}=-41,300+1,158 \mathrm{X}$. Hal ini menunjukkan bahwa disposisi matematis memiliki pengaruh yang signifikan terhadap prestasi belajar $e$-learning mahasiswa.
\end{abstract}

Kata Kunci:

Disposisi Matematis, Prestasi Belajar, E-Learning

\section{Abstract:}

Learning online in order to be successful requires high student interest in learning mathematics. High interest in learning mathematics is called a mathematical disposition. This study aims to determine whether there is an effect of mathematical disposition on e-learning learning achievement of Mathematics Tadris (TMA) III Semester students at IAIN Takengon. The population in this study were students of TMA IAIN Takengon. Samples were selected by purposive sampling technique and selected third semester TMA students. The approach used is a quantitative approach with the type of correlation research. The research instrument used tests and non-tests. This study was analyzed using the normality test, linearity test, heteroscedasticity test, and simple linear regression test. Based on regression testing, it is known that the value of sig $=0.003<0.05$, which means that mathematical disposition has a significant effect on e- 
learning achievement. In addition, the value of $R$ square $=0.848$ shows that the mathematical disposition variable affects the e-learning learning achievement variable by $84.8 \%$ and $16.4 \%$, the e-learning learning achievement variable is influenced by factors outside of mathematical disposition. The magnitude of the correlation coefficient $(R)$ is 0.921 , which means that there is a strong relationship between mathematical disposition and e-learning achievement. The regression model is $Y=-41,300+X 1,158$. This shows that mathematical disposition has a significant effect on student e-learning achievement.

\section{Keywords:}

Mathematical Disposition, Learning Achievement, E-Learning

\section{A. Pendahuluan}

Pandemi covid-19 memberikan dampak terhadap berbagai aspek bidang salah satunya pendidikan. Dampak dalam pendidikan bukan hanya dirasakan pendidikan dasar dan menengah tetapi juga perguruan tinggi. Dampak covid-19 tersebut yaitu perubahan pembelajaran tatap muka menjadi pembelajaran secara daring. Salah satu model pembelajaran yang dapat digunakan secara daring yaitu model pembelajaran E-learning.

Menurut Rosenberg (2001) e-learning merupakan pembelajaran yang menggunakan teknologi internet untuk mengirimkan serangkaian solusi untuk meningkatkan pengetahuan dan keterampilan. E-learning menekankan pada penggunaan internet dalam pembelajaran (Kamarga, 2002). Sedangkan menurut Mason dan Rennie (2010) e-learning sebagai pembelajaran berbasis perangkat elektronik telah merubah proses tarnsformasi pendidikan konvensional ke bentuk digital baik isi maupun system. Dari definisi tersebut dapat disimpulkan bahwa e-learning merupakan pembelajaran berbasis teknologi internet dan perangkat elektronik. Pembelajaran e-learning menuntut mahasiswa mandiri, bertanggung jawab, dan berperan aktif dalam pembelajaran.

Pembelajaran e-learning juga diterapkan pada mahasiswa tadris matematika IAIN Takengon. Berdasarkan hasil observasi dan wawancara diketahui bahwa dosen untuk menjelaskan matematika yang sifatnya abstrak berupa unsur, definisi, aksioma, dan dalil-dalil menggunakan media aplikasi google classroom, edmodo, zoom, dan youtube. Penggunaan media tersebut memiliki kelemahan seperti pembelajaran $e$-learning satu arah menimbulkan kurangnya interaksi antara mahasiswa dan dosen, sulitnya mengontrol antara mahasiswa yang serius belajar dengan yang tidak, serta materi perkuliahan direspon berdasarkan tingkat pemahaman mahasiswa sehingga tidak semua mahasiswa memahami secara cepat penjelasan dosen secara daring. Agar pembelajaran daring dapat berhasil perlu adanya ketertarikan mahasiswa yang tinggi dalam belajar matematika. Ketertarikan yang tinggi terhadap pembelajaran matematika disebut dengan disposisi matematis.

Menurut Kilpatrick, Swafford dan Findell (2001: 131) menyatakan bahwa disposisi matematis merupakan rasa ketertarikan mahasiswa yang tinggi karena menganggap bahwa matematika merupakan ilmu yang bermanfaat bagi kehidupan serta yakin bahwa mempelajari matematika dengan sungguh-sungguh akan membuahkan hasil dan melakukan perbuatan sebagai pelajar dan pekerja matematika yang efektif. Menurut NCTM (2003) menyatakan bahwa disposisi matematis adalah keterkaitan dan apresiasi terhadap matematika, yaitu suatu kencenderungan untuk berpikir dan bertindak dengan cara yang positif. Sedangkan menurut Sumarmo (2010: 7) menyatakan bahwa disposisi matematis adalah keinginan, kesadaran, kecenderungan, dan dedikasi yang kuat pada diri mahasiswa untuk berpikir dan bertindak secara matematis. Dari beberapa pernyataan di atas dapat disimpulkan bahwa disposisi matematis adalah ketertarikan, kecenderungan, apresiasi dan dedikasi.

Mahmudi (2010: 48) menyatakan bahwa disposisi matematis merupakan salah satu faktor penunjang keberhasilan belajar matematika siswa. Selain itu didukung oleh pernyataan Sumarmo (2013: 91) bahwa seseorang yang memiliki disposisi matematis yang tinggi akan membentuk individu yang tangguh, ulet, bertanggung jawab, memiliki motif berprestasi yang tinggi, serta membantu individu mencapai hasil terbaiknya. Keberhasilan dalam belajar sering 
ditandai dengan tingginya prestasi belajar. Dari uraian di atas penelitian ini bertujuan untuk mengatahui pengaruh disposisi matematis mahasiswa terhadap prestasi belajar matematika dengan menggunakan e-learning.

\section{B. Kajian Teoritis}

\section{Disposisi Matematis}

Menurut Mulyana (2009: 19) disposisi matematis adalah afinitas dan penghargaan terhadap matematika berupa kecenderungan untuk berpikir dan bertindak secara positif, percaya diri, keingintahuan, ketekunan, antusias dalam belajar, gigih menghadapi permasalahan, fleksibel, mau berbagi dengan orang lain, refleksi dalam kegiatan matematik (doing math). Sedangkan menurut Katz (1993) menyatakan bahwa disposisi merupakan kecenderungan untuk berperilaku secara sadar (consciously), teratur (frequently), dan sukarela (voluntary) (Mahmudi, 2010:5) untuk mencapai tujuan tertentu. Menurut NCTM (1989:233), disposisi dapat dilihat sebagai kecenderungan seseorang dalam berpikir dan bertindak secara positif. Dari tiga definisi di atas dapat disimpulkan bahwa disposisi matemtais adalah kecenderungan untuk berpikir dan bertindak positif dalam kegiatan matematik.

Menurut NCTM (1989: 233) terdapat beberapa indikator-indikator disposisi matematis, antara lain: (a) Rasa percaya diri dalam memakai matematika, menyelesaikan masalah, mengkomunikasikan ide, dan mengutarakan alasan. (b) Fleksibilitas dalam menyelidiki ide matematik dan berupaya menemukan ide lain dalam menyelesaikan masalah. (c) Giat mengerjakan tugas matematik. (d) Tingginya minat, rasa ingin tahu, dan menemukan jawaban dalam melaksanakan tugas matematik. (e) Cenderung mengawasi dan mengevaluasi kinerja dan penalaran mereka sendiri. (f) Menilai penerapan matematika ke kondisi lain dalam bidang lainnya dan pengalaman kehidupan sehari-hari. (g) Penghargaan peran matematika dalam budaya dan nilai matematika, sebagai alat dan bahasa.

\section{E-learning}

Menurut Prakoso (2005) e-learning merupakan pembelajaran dengan perangkat komputer tersambung ke internet, dimana mahasiswa berupaya mendapatkan bahan belajar sesuai kebutuhannya, e-learning adalah aplikasi internet yang menghubungkan dosen dan mahasiswa melalui ruang belajar online. E-learning adalah sebuah proses pembelajaran yang dilakukan dengan berbantuan perangkat elektronik melalui network (jaringan komputer), baik yang berupa internet atau intranet (Hakim, 2018: 169). Sedangkan menurut Munir (2009: 169) menyatakan bahwa e-learning adalah suatu bentuk teknologi informasi yang dipakai dibidang pendidikan dalam bentuk dunia maya sebagai upaya untuk membuat sebuah transformasi proses pembelajaran ke dalam bentuk digital yang dijembatani melalui internet. Dari definisi di atas dapat disimpulkan bahwa e-learning adalah pembelajaran berbantuan perangkat elektronik baik melalui internet maupun intranet.

Kelebihan dari e-learning menurut Kusmana (2011: 39) adalah: (a) Tersedianya fasilitas e-moderating dimana dosen dan mahasiswa dapat berkomunikasi dengan mudah melalui fasilitas internet secara teratur atau kapan saja tanpa dibatasi jarak, tempat, dan waktu. (b) Dosen dan mahasiswa dapat memakai bahan ajar yang terstruktur dan terjadwal melalui internet, sehingga keduanya dapat saling mengetahui sampai seberapa jauh bahan ajar dipelajari. (c) Mahasiswa dapat belajar atau mereview bahan ajar kapanpun dan dimanapun. (d) Mahasiswa dapat memperoleh tambahan informasi yang terkait dengan bahan yang dipelajarinya melalui internet. (e) Diskusi melalui internet dapat diikuti dengan jumlah peserta yang banyak. (f) Berubahnya peran mahasiswa dari yang biasanya pasif menjadi aktif. (g) Cenderung efisien. Sedangkan kekurangan pembelajaran e-learning menurut Kusmana (2011: 39) adalah: (a) Minimnya interaksi antara dosen dan mahasiswa serta antar mahasiswa akan dapat memperlambat terbentuknya nilai dalam proses belajar mengajar. (b) Dosen dituntut mengetahui teknik pembelajaran ICT. (c) Mahasiswa yang tidak memiliki motivasi belajar yang tinggi akan mengalami kegagalan. 


\section{Metode Penelitian}

1. Jenis Penelitian

Penelitian ini menggunakan pendekatan kuantitatif dengan jenis penelitian korelasi. Alasan peneliti memilih penelitian kuantitatif karena ingin mengetahui pengaruh disposisi matematis tehadap prestasi belajar e-learning.

\section{Waktu dan Tempat Penelitian}

Penelitian dilakukan di kampus IAIN Takengon Aceh Tengah dengan waktu penelitian bulan September-Oktober 2020.

\section{Target/Subjek Penelitian/Populasi dan Sampel}

Populasi dalam penelitian ini adalah mahasiswa Tadris Matematika IAIN Takengon. Sample dipilih dengan teknik purposive sampling terpilih mahasiswa TMA semester III. Alasan penggunaan purposive sampling karena mata kuliah aljabar linier yang diteskan merupakan mata kuliah yang terdapat pada TMA semester III.

\section{Desain Penelitian}

Desain penelitian yang digunakan adalah desain penelitian one shot case study. Desain one shot case study dapat dilihat pada Tabel 1.

Tabel 1. Desain Penelitian

\begin{tabular}{lcc}
\hline Kelas & Perlakuan & Akhir \\
\hline Eksperimen & $\mathrm{X}$ & $\mathrm{O}$
\end{tabular}

Keterangan:

$\mathrm{X}:$ Perlakuan (pembelajaran e-learning)

O: Postest

\section{Intrumen, dan Teknik Pengumpulan Data}

Instrumen penelitian menggunakan tes dan non tes. Non tes digunakan untuk memperoleh data mengenai disposisi matematis sedangkan tes digunakan untuk memperoleh data prestasi belajar e-learning. Tes pembelajaran e-learning terdiri dari 5 soal sedangkan angket disposisi matematis terdiri dari 25 butir pernyataan. Teknik pengumpulan data menggunakan tes, angket. dan dokumentasi. Tes yang diujikan adalah tes pada mata kuliah aljabar linier. Validitas dan reliabilitas tes diperoleh dari hasil ujicoba terhadap mahasiswa semester $\mathrm{V}$ yang telah menerima mata kuliah aljabar linier. Uji validitas menggunakan korelasi product moment dan reliabilitas menggunakan rumus alpha.

\section{Teknik Analisis Data}

Setelah data terkumpul maka kegiatan selanjutnya adalah analisis data. Teknik analisis data yang digunakan dalam penelitian ini adalah uji normalitas, uji linieritas, uji heteroskedastisitas dan uji regresi.

\section{Hasil Penelitian dan Pembahasan}

Data yang diperoleh dalam penelitian ini adalah data disposisi matematis yang diperoleh dari angket dan data prestasi belajar yang diperoleh dari tes yang diberikan ke mahasiswa. Sebelum dilakukan uji hipotesis Regresi terlebih dahulu dilakukan uji prasyarat antara lain uji normalitas, uji linieritas, dan uji heteroskedastisitas. 


\section{Hasil}

\section{a. Uji Normalitas}

Uji normalitas digunakan untuk mengetahui apakah data yang diperoleh berdistribusi normal atau tidak. Uji normalitas dalam penelitian ini menggunakan uji Kolmogorov Smirnov. Kriteria pengujian dengan taraf kesalahan 5\% atau 0,05 adalah jika nilai signifikansi lebih besar dari 0,05 maka data berdistribusi normal, sedangkan jika kurang dari 0,05 maka tidak berdistribusi normal. Berikut hasil uji normalitas yang disajikan pada Tabel 2 .

Tabel 2. Uji Normalitas Kolmogorov Smirnov

\begin{tabular}{lcccc}
\hline & \multicolumn{3}{c}{ Kolmogorov-Smirnov } & \multirow{2}{*}{ Keterangan } \\
\cline { 2 - 4 } & Statistic & df & Sig & \\
\hline Disposisi Matematis & .198 & 7 & .200 & Berdistribusi Normal \\
Prestasi Belajar Matematika & .292 & 7 & .072 & Berdistribusi Normal \\
\hline
\end{tabular}

Bedasarkan hasil analisis data untuk disposisi matematis dengan $\alpha=0,05$ pada output diperoleh sig $=0,200>0,05$ berarti data disposisi matematis berdistribusi normal. Untuk data prestasi belajar $e$-learning dengan $\alpha=0,05$ pada output diperoleh sig $=0,072>0,05$ berarti data prestasi belajar e-learning berdistribusi normal.

\section{b. Uji Linieritas}

Uji linieritas diperoleh dengan melihat Gambar 1.

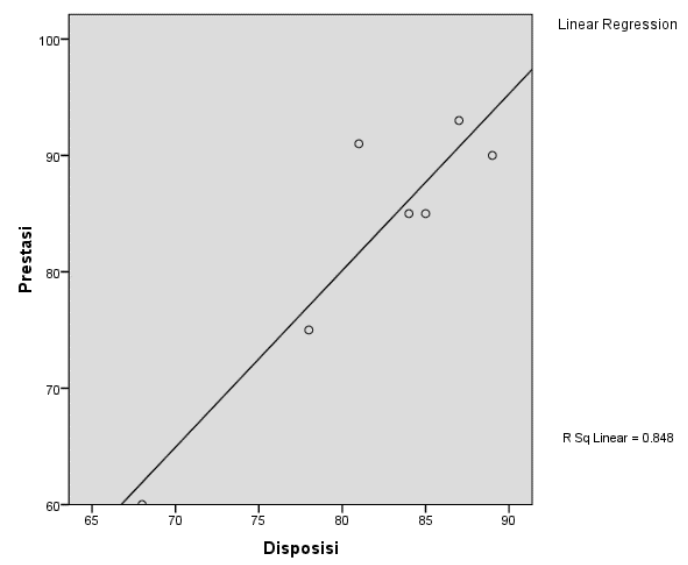

\section{Gambar 1. Scatter Plot dan Garis Regresi}

Pada Gambar 1 tampak bahwa scatter plot disertai dengan garis regresi yang mengarah ke kanan atas menunjukkan adanya linieritas pada hubungan antara variabel disposisi matematis dengan prestasi belajar e-learning (Sukestiyarno, 2011).

\section{c. Uji Heteroskedastisitas}

Uji heteroskedastisitas diperoleh dengan melihat Gambar 2. Berdasarkan Gambar 2 diketahui bahwa penyebaran titik tidak membentuk pola bergelombang melebar kemudian menyempit dan melebar kembali, dan penyebaran titik data tidak berpola. Dengan demikian dapat disimpulkan bahwa tidak terjadi masalah heteroskedastistas. 
Scatterplot

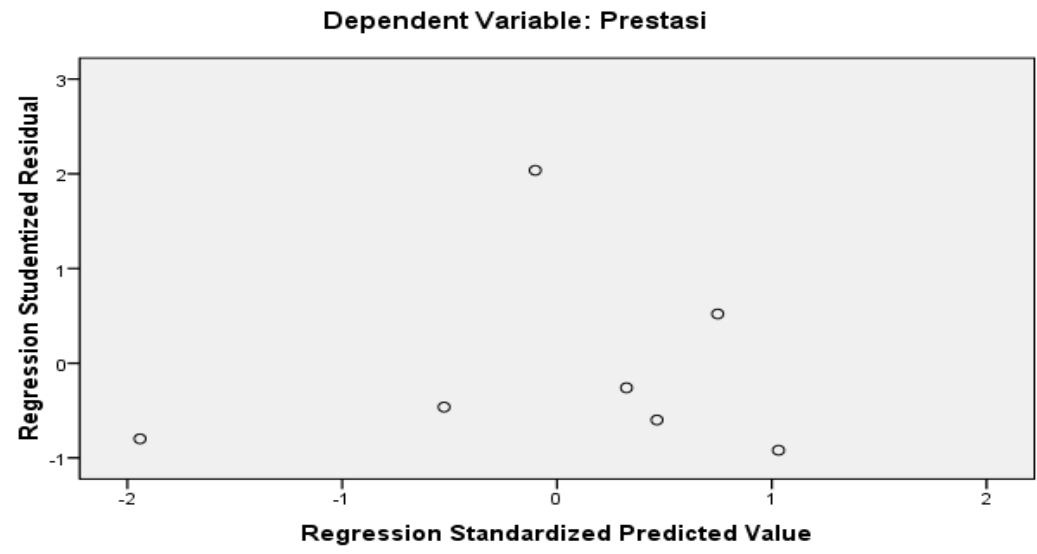

Gambar 2. Scatterplot Uji Heteroskedastisitas

\section{d. Uji Regresi}

Uji regresi digunakan untuk mengetahui apakah terdapat pengaruh disposisi matematis terhadap prestasi belajar e-learning. Hasil pengujian disajikan sebagai pada Tabel 3.

Tabel 3. Uji Regresi Disposisi Matematis Terhadap Prestasi Belajar E-Learning

\begin{tabular}{lllccc}
\hline Model & $\begin{array}{l}\text { Sum of } \\
\text { Square }\end{array}$ & df & Mean Square & F & Sig \\
\hline Regression & 689.665 & 1 & 689.665 & 27.862 & $.003^{\mathrm{a}}$ \\
Residual & 123.764 & 5 & 24.753 & & \\
Total & 813.429 & 6 & & & \\
\hline
\end{tabular}

a.Predictors (Constant), Disposisi

Tabel 4. Uji Koefisien Determinasi R Square

\begin{tabular}{lcccc} 
Model & R & R Square & $\begin{array}{c}\text { Adjusted R } \\
\text { Square }\end{array}$ & $\begin{array}{c}\text { Std.Error Of } \\
\text { The Estimate }\end{array}$ \\
\hline & $.921^{\mathrm{a}}$ & .848 & .817 & 4.975 \\
\hline
\end{tabular}

a.Predictors;(Constant), Disposisi

Berdasarkan pengujian regresi pada Tabel 3 diketahui nilai sig $=0,003<0,05$ yang berarti bahwa disposisi matematis memiliki pengaruh signifikan terhadap prestasi belajar e-learning. Selain itu dapat dilihat pada Tabel 4 diketahui nilai $\mathrm{R}$ square $=0,848$ menunjukan bahwa variable disposisi matematis mempengaruhi variable prestasi belajar e-learning sebesar $84,8 \%$ dan $16,4 \%$ variabel prestasi belajar e-learning dipengaruhi factor diluar disposisi matematis. Besarnya koefisien korelasi $(\mathrm{R})$ adalah 0,921 yang artinya terdapat hubungan yang kuat antara disposisi matematis dengan prestasi belajar e-learning.

Hasil pengujian koefisien disposisi matematis terhadap prestasi belajar e-learning disajikan pada Tabel 5. Berdasarkan Tabel 5. disposisi matematis terhadap prestasi belajar $e$ learning diperoleh nilai a (konstanta) $=-41,300, \mathrm{~b}$ (koefisien regresi $)=1,518$, dengan demikian persamaan regresinya adalah $\mathrm{Y}=-41,300+1,158 \mathrm{X}$. Persamaan regresi tersebut terlihat bahwa nilai konstanta $-41,300$ bernilai negarif artinya jika variabel disposisi matematis bernilai 0 maka prestasi belajar e learning nilaninya sebesar $-41,300$. Untuk koefisien regresi linier variabel disposisi matematis sebesar 1,518 bernilai positif menyatakan bahwa setiap penambahan 1 disposisi matematis maka nilai prestasi belajar e learning bertambah 1,518. 
Tabel 5. Uji Koefisien Pengaruh Disposisi Matematis Terhadap Prestasi Belajar ELearning

\begin{tabular}{lccccc}
\hline Model & \multicolumn{2}{c}{$\begin{array}{c}\text { Unstandardized } \\
\text { Coefficients }\end{array}$} & $\begin{array}{c}\text { Standardized } \\
\text { Coefficients }\end{array}$ & t & Sig \\
\cline { 2 - 4 } & $\mathrm{B}$ & Std.Error & Beta & & \\
\hline (Constant) & $-41.300^{\mathrm{a}}$ & 23.569 & & -1.752 & .140 \\
Disposisi & 1.518 & .288 & .921 & 5.278 & .003 \\
\hline
\end{tabular}

a.Dependent Variable: Prestasi

\section{Pembahasan}

Berdasarkan uji normalitas diketahui data untuk disposisi matematis dengan $\alpha=0,05$ pada output diperoleh sig $=0,200>0,05$ berarti data disposisi matematis berdistribusi normal. Untuk data prestasi belajar e-learning dengan $\alpha=0,05$ pada output diperoleh sig $=0,072>0,05$ berarti data prestasi belajar e-learning berdistribusi normal. Karena data disposisi matematis dan prestasi belajar e-learning berdistribusi normal maka dapat dilanjutkan uji selanjutnya yaitu uji linieritas dan uji heteroskedastisitas. Uji linieritas digunakan untuk mengetahui linieritas hubungan antara disposisi matematis dan prestasi belajar e-learning. Uji normalitas, uji linieritas dan uji heteroskedastisitas merupakan uji prasyarat sebelum dilakukan uji regresi.

Berdasarkan hasil analisis data uji regresi diketahui bahwa nilai sig $=0,003<0,05$ dapat disimpulkan bahwa disposisi matematis berpengaruh signifikan terhadap prestasi belajar $e$ learning. Hal ini menunjukkan bahwa mahasiswa yang memiliki disposisi matematis yang tinggi cenderung membentuk individu yang tangguh, ulet, bertanggung jawab, memiliki motif berprestasi yang tinggi, serta membantu individu mencapai hasil terbaiknya. Dengan ketekunan dan motivasi belajar yang tinggi, mahasiswa akan lebih berusaha dalam menyelesaikan soal-soal matematika yang diberikan serta mahasiswa akan berusaha mencari solusi setiap permasalahan yang dihadapi pada saat pembelajaran $e$ learning. Hal ini didukung juga dengan hasil penelitian Mayratih (2019: 47) yang menyatakan bahwa disposisi matematis merupakan salah satu factor yang menentukan keberhasilan siswa dalam proses pembelajaran. Selain itu pernyataan tersebut juga didukung hasil penelitian Annajmi (2018: 7) yang menyatakan bahwa disposisi matematis berkontribusi positif terhadap prestasi belajar matematika dengan koefisien determinasi sebesar $21,9 \%$ dan $78 \%$ dipengaruhi factor lain seperti minat, kemampuan kognitif, pemahaman matematis mahasiswa dan lainnya.

Nilai $\mathrm{R}$ square sebesar 0,848 menunjukan bahwa variable disposisi matematis mempengaruhi variable prestasi belajar e-learning sebesar $84,8 \%$ dan $16,4 \%$ variabel prestasi belajar e-learning dipengaruhi factor diluar disposisi matematis seperti minat, motivasi, kemampuan kognitif, pemahaman matematis dan lainnya. Dari data tersebut dapat diketahui bahwa disposisi matematis menjadi factor terbesar dibanding dengan faktor lainnya. Hal ini menunjukkan bahwa disposisi matematis memiliki pengaruh yang signifikan terhadap perstasi belajar e-learning mahasiswa. Dengan disposisi matematis yang tinggi mahasiswa akan mampu memperoleh keberhasilan dalam belajar.

\section{E. Simpulan}

Berdasarkan penelitian yang dilaksanakan dapat disimpulkan bahawa disposisi matematis berpengaruh signifikan terhadap prestasi belajar e-learning hal ini dapat dilihat dari nilai sig $=$ $0,003<0,05$. Selain itu juga variable disposisi matematis mempengaruhi variable prestasi belajar e-learning sebesar $84,8 \%$ dan $16,4 \%$ variabel prestasi belajar e-learning dipengaruhi faktor diluar disposisi matematis. 


\section{DAFTAR PUSTAKA}

Annajmi. (2018). Kontribusi disposisi matematis terhadap prestasi belajar matematika siswa kelas viii smpn 3 Tambusai. Jurnal Edumatica, 8(1), 1-8.

Hakim, R, A. (2018). Pengembangan e-learning berbasis moodle sebagai media pengelolaan pembelajaran. Jurnal Kodifikasia, 12(2), 167-183.

Kamarga, Hanny. (2002). Belajar sejarah melalui e-learning; Alternatif mengakses sumber informasi kesejarahan. Jakarta: Inti Media.

Katz, L. G. (1993). Disposition: Definition and implications for early childhood practices. Perspective from ERIC/EECE: A Monograph Series No.4. Catalog No. 211.

Kilpatrick, J. Swafford, J. \& Findell, B. (2001). Adding it up: Helping children learn mathematics. Washington, DC: National Academy Press.

Kusmana, Ade.(2011). E-learning dalam pembelajaran. Jurnal LENTERA PENDIDIKAN, 14(1), $35-51$.

Mahmudi, A. (2010). Tinjauan asosiasi antara kemampuan pemecahan masalah matematis dan disposisi matematis. Prosiding, Seminar Nasional Pendidikan UNY, 17 April 2010. Yogyakarta: FMIPA UNY

Mason, Robin \& Rennie, F. (2010). E-learning: Panduan lengkap memahami dunia digital dan internet, trans, 1st ed. Yogyakarta: Baca

Mayratih, G. E., Leton, S. I. \& Uskono, V. I. (2019). Pengaruh disposisi matematis terhadap kemampuan pemecahan masalah matematis siswa. Jurnal ASIMTOT, 1(1), 41-49.

Mulyana, E. (2009). Pengaruh model pembelajaran matematika knisley terhadap peningkatan pemahaman dan disposisi matematis siswa SMA program IPA. Disertasi, tidak dipublikasikan. UPI.

Munir. (2009). Pembelajaran jarak jauh berbasis teknologi informasi dan komunikasi. Bandung: Alfabeta.

National Council of Teacher of Mathematics (NCTM). (1989). Curriculum and evaluation standards for school mathematics. Reston, VA: Authur.

NCTM. (2003). Standards for secondary mathematics teachers. [Online]. Tersedia: http://www.ncate.org.

Prakoso, Setiyo. (2005). Membangun e-learning dengan moodle. Jakarta: Andi Opsett.

Rosenberg Mark J. (2001). E-learning strategies for delivering knowledge in the digital. New York: McGraw Hill.

Sukestiyarno. (2011). Olah data penelitian berbantuan spss. Semarang: Universitas Negeri Semarang.

Sumarmo, U. (2003). Daya dan disposisi matematik: Apa, mengapa dan bagaimana dikembangkan pada siswa sekolah dasar dan menengah. Makalah disajikan pada seminar sehari di Jurusan Matematika ITB.

Sumarmo, U. (2012). Pendidikan karakter serta pengembangan berpikir dan disposisi matematik dalam pembelajaran matematika. Disajikan pada Seminar Pendidikan Matematika, 25 Februari 2012. 